\title{
BADANIA BIOGRAFICZNE JAKO ŹRÓDŁO REFLEKSJI NAD PROCESAMI NAUCZANIA/UCZENIA SIĘ JĘZYKÓW OBCYCH
}

\author{
Biographical studies as a source of reflection on the process \\ of foreign teaching and learning
}

If reflection is the necessary condition for successful development of all participants of the process of foreign language teaching and learning, as well as for the evolution of the scientific discipline, as we may now call glottodidactics, it is worth looking for all possible examples of it. In the light of this, the author of this article develops the thesis that appropriately designed studies based on biographies may provide rich and useful material for reflection on foreign language learning and teaching. The author also attempts to explain why biographical research is so rarely used in Polish glottodidactic studies and if this state of affairs could be changed.

Keywords: biographical studies, reflection, foreign language learning and teaching, glottodidactics

Słowa kluczowe: badania biograficzne, refleksja, nauczanie i uczenie się języka obcego, glottodydaktyka

\section{Wprowadzenie}

Choć w granicach wiedzy specjalistycznej, jak choćby w psychologii czy filozofii, „refleksja” jawi się jako pojęcie zawiłe i wieloznaczne (por. Chudy, 2006: 68-n.), to w opracowaniach słownikowych przeznaczonych do powszechnego użytku definiowana jest w sposób zwięzły i klarowny. Najczęściej przyjmuje się jej dwa zasadnicze wyjaśnienia: 1) „refleksja” jako świa- 
doma czynność umysłowa, polegająca na głębszym zastanowieniu się, rozmyślaniu, rozważaniu połączonym z analizą, wyjaśnieniem, tłumaczeniem, przewidywaniem itp., 2) lub „refleksja” jako rezultat takiej czynności, przyjmujący postać określonych wniosków lub twierdzeń (por. Doroszewski, 1963: 873; Sobol, 2002: 831).

Dla potrzeb niniejszych rozważań, tematycznie ukierunkowanych na zagadnienie nauczania/uczenia się języków obcych - uściślając: na pogłębianie wiedzy o tych procesach i warunkujących je czynnikach - taka definicja wydaje się wystarczająca. Zastrzec jedynie należy, że zarówno w pierwszym, jak i drugim przypadku „refleksja” może przejawiać się w dwóch wymiarach, w pewnym sensie w mikro- i makro-skali (por. Kic-Drgas, 2010: 113).

Pierwszy wymiar ma charakter ściśle subiektywny. $W$ takim rozumieniu „refleksja” - dla rozróżnienia: „autorefleksja” - jest wynikiem indywidualnej aktywności umysłowej konkretnego człowieka i dotyczy jego podmiotowej działalności, a więc jest skierowana wyłącznie na jego własne "ja”, konstytuuje jego tożsamość i osobisty rozwój.

Drugi wymiar, w jakim może manifestować się i jakiego może dotyczyć „refleksja”, ma charakter przedmiotowy. W tym ujęciu u podstaw refleksji leżą nie tyle własne wiedza, doświadczenia i procesy psychiczne konkretnej jednostki, choć i te nie są tu bez znaczenia, co czynione przez nią obserwacje „świata zewnętrznego". Jest to zbiór typowo faktograficznych informacji na określony temat, również informacji o charakterze refleksyjnym, a więc i subiektywnych. Informacje te napływają z otoczenia samoistnie bądź są uzyskiwane od innych członków danej grupy społecznej w sposób wymuszony - sterowany stosowną metodologią i różnego typu narzędziami, którym można przypisać status metod i narzędzi własnych, nieprofesjonalnych i nienaukowych lub przeciwnie - naukowo sprawdzonych oraz uznanych w obszarze danej dyscypliny.

$Z$ perspektywy naukowo-badawczej o przedmiotowym wymiarze „refleksji" można mówić zatem wówczas, gdy rodzajowo pogrupowane i tematycznie ukierunkowane refleksje uczestników badania stają się przedmiotem zainteresowania badacza, składają się na pewną całość lub całość tę dopełniają i w sprzyjających warunkach, zwykle wskutek ich szeroko pojętej analizy - ilościowej, jakościowej lub mieszanej - mogą być źródłem jego własnej, pogłębionej refleksji na określony temat. Uogólniając, pozwalają badaczowi uchwycić jakiś wycinek badanej przezeń rzeczywistości z innej perspektywy, niekiedy zupełnie nieznanej. Tym samym rozszerzają jej dotychczasowe opisy, niejako umożliwiając i zarazem obligując go do uwzględnienia tych zmian na etapie budowania nowych lub co najmniej rekonstruowania ogłoszonych już teorii, koncepcji czy tez, opisujących lub wyjaśniających rządzące tą rzeczywistością zasady, jak i zachodzące w niej procesy. 


\section{Status „refleksji” w badaniach biograficznych}

Naukowych, a więc metodologicznie ugruntowanych sposobów dotarcia do tego typu informacji - informacji o znamionach refleksji w wymiarze przedmiotowym - jest wiele. Jednym z nich są badania biograficzne, a dokładniej: badania bazujące na metodzie biograficznej. Tu znów, posiłkując się zwięzłą definicją, można przyjąć, że metoda biograficzna jest przejawem badań historycznych i odnosi się do wszelkiego typu biografii zastanych (np. listów, dzienników, pamiętników, innych dokumentów osobistych, takich jak: notatki osobiste, sprawozdania, protokoły, teczki personalne itp., spisanych biografii lub autobiografii, literatury faktu, filmów, blogów internetowych) oraz wywołanych (np. wywiadów narracyjnych, opowiadań o życiu). Polega ona na opisie i analizie przebiegu życia ludzkiego, często jednostek wybitnych bądź z różnych względów interesujących, które rozpatrywane jest w kontekście określonego wycinka rzeczywistości, w ujęciu całościowym bądź fragmentarycznym, ze szczególnym zwróceniem uwagi na wybrany, znajdujący się w zainteresowaniu badacza, rodzaj działalności, konkretny aspekt życia. $\mathrm{W}$ istocie metoda ta jest więc konglomeratem różnych innych metod i technik badawczych, jak chociażby: analiza dokumentów, obserwacja, metoda sondażu, metoda dialogowa. Sprzężone, w pewien osobliwy sposób pozwalają one wniknąć badaczowi w przeszłość, poznać zarówno obiektywnie odnotowane fakty historyczne, jak i ich subiektywne, jednostkowe opisy czy relacje.

Warto dopowiedzieć, że w ramach metody biograficznej funkcjonują dwie submetody czy też odmiany metody biograficznej. Pierwsza z nich to „metoda indywidualnych przypadków”, której celem, uogólniając, jest zbadanie biegu bądź wybranego okresu życia jednostki. Druga to „metoda monograficzna”, zazwyczaj wykorzystywana w celu poznania i oceny mechanizmów funkcjonowania różnego typu placówek i instytucji (opiekuńczych, wychowawczych, kształcących, itd.). I jedna i druga może być stosowana w retrospektywnym wymiarze badań lub w badaniach typowo porównawczych, zmierzających do konfrontacji danych historycznych ze stanem obecnym, współczesnym (por. Rzepa, Leoński, 1993: 8-13; Sipińska, 2004: 156; Łobocki, 2006: 293-n.; Pilch, Bauman, 2010: 300).

Metoda biograficzna wspiera się na tezie, że wiedza o społeczeństwie, do której badacz próbuje dotrzeć m.in. za jej pośrednictwem, jest zawsze „czyjąś" wiedzą i że są takie wymiary rzeczywistości społecznej, których pełny opis i zrozumienie są możliwe jedynie wówczas, gdy zostaną uwzględnione nie tylko dane faktograficzne - zwane niekiedy obiektywnymi - najczęściej kojarzone z zapisami o charakterze ilościowym i statystycznym, ale i subiektywne ich opisy oraz interpretacje (Pilch/Bauman, 2010: 301). Szeroko pojęty proces 
kształcenia jest niewątpliwie jednym z takich złożonych wymiarów (por. Milerski, Śliwerski, 2000: 106). Nie można mówić o jego poznaniu bez wnikliwej analizy związków i zależności występujących pomiędzy uczestnikami tego procesu. I nie chodzi tu jedynie o wniknięcie w relacje łączące uczniów i nauczycieli, o uchwycenie ich punktu widzenia na pewne istotne bądź mniej istotne kwestie - w gruncie rzeczy o ich znaczeniu musi rozstrzygnąć sam podmiot badania. Niezwykle ważne okazuje się również dogłębne poznanie otoczenia tworzonego przez nich układu komunikacyjnego, zbadanie szeroko pojętego kontekstu, który w sposób bezpośredni bądź co najmniej pośrednio warunkuje zachodzące $w$ tym układzie procesy zdobywania wiedzy czy nauczania i uczenia się ściśle określonych kompetencji - w zależności od profilu kształcenia. W procesie poznawczym, zwłaszcza gdy pod rozwagę brany jest rozwój jakiejś dyscypliny naukowej, której zadaniem jest kompleksowe rozpoznanie, opis, wyjaśnienie oraz stałe usprawnianie tej domniemanej rzeczywistości, indywidualne refleksje uczestników tego układu, jak też uczestników i twórców otaczającego go systemu, są więc dla badacza szczególnie cenne. Powracając myślą do przywołanej wcześniej definicji, można wprost stwierdzić, że są to ich wnioski i przemyślenia z przeżytych doświadczeń i poczynionych obserwacji z czasu, gdy w tym układzie/systemie uczestniczyli. Co więcej, także stricte naukowe refleksje, czynione w przeszłości przez poprzedników współczesnych badaczy, nie powinny stać się przedmiotem zupełnego zapomnienia, lecz, stosownie do potrzeb i możliwości, winny być przywoływane, a nawet powtórnie przez nich analizowane - z nowej perspektywy.

Przechodząc do meritum, warto odnotować wątek, na którego rozwinięcie nie wystarczy tu miejsca, a który niewątpliwie jest ważny i jego zgłębienie z perspektywy badań glottodydaktycznych również byłoby wskazane. Dla wygody, ale i uznania trafności poniższej tezy, posłużę się tu cytatem zaczerpniętym ze wstępu jednej z monografii, poświęconej w całości metodzie biograficznej - jak się okazuje, jednej z nielicznych w polskim piśmiennictwie:

(...) Stosunek do metody biograficznej przypomina podstawowy mechanizm gry komunikacyjnej typu <<tak, ale»>. Oto piszący o metodzie biograficznej zwykle podnoszą ogromną atrakcyjność studiów biograficznych (...) podkreślają, iż to w biografii zbiegają się wątki psychologiczne, społeczne, historyczne, ekonomiczne, geograficzne etc.; że w biografii odsłaniają się - konstytutywne dla jednostki, grupy i społeczeństwa - związki postaw z wartościami oraz wzajemne uwikłania indywidualne, grupowe i społeczne. Stwarza to (...) możliwość poznania i zrozumienia głębi funkcjonowania jednostki, grupy czy społeczeństwa, jak również możliwość weryfikowania rozmaitych założeń teoretycznych, wręcz całych teorii wyjaśniających sens zachowań na każdym z tych szczebli funkcjonowania (...). To są główne argumenty na rzecz 
<<tak>>, przemawiające za metodą biograficzną. Z drugiej zaś strony, ci sami autorzy wskazują na wszelkie <<ale>> metody biograficznej. Stwierdzają, że podstawą metody są retrospektywne i introspekcyjne dane o wątpliwej wiarygodności. Dlatego też metoda umożliwia wyłącznie stawianie hipotez, nie zaś ich testowanie. Zwracają również uwagę na to, że metoda biograficzna pozostaje zbyt otwarta na różnorodne, nawet przeciwstawne, wyjaśnienia, zależne od sposobu selekcji materiałów i wyboru teorii wyjaśniającej. Metodzie tej nie przysługują zatem walory obiektywności, reprezentatywności ani też jednorodności (porównywalności) (...) (por. Rzepa, Leoński, 1993: 7-8).

Mając świadomość tej dychotomii, raz jeszcze warto podkreślić potrzebę dogłębnej weryfikacji wartości naukowej, ale i oszacowania negatywnych konsekwencji, jakie może rodzić włączenie metody biograficznej w zakres badań glottodydaktycznych. Jednocześnie, w świetle przedmiotu zainteresowań glottodydaktyki, jej zakresu badawczego i wyznaczonych zadań (por. np. Grucza, 1978; Woźniewicz, 1987; Dakowska, 2008; Wilczyńska i Michońska-Stadnik, 2010), metoda ta wydaje się godna uwagi pod warunkiem, że w badaniach będzie pełniła funkcję pomocniczą, uzupełniającą. Jest to oczywiście subiektywna, w dodatku wstępna ocena.

\section{Badania biograficzne jako źródło refleksji w glottodydaktyce}

Punktem wyjścia do dalszych rozważań niech będą słowa polskiego metodologa specjalizującego się w dziedzinie pedagogiki, z którą glottodydaktyka jest przecież powiązana i z dorobku której, zwłaszcza jeśli chodzi o metodologię badań, w dalszym ciągu bardzo często korzysta:

Wychowanie, kształcenie i samokształcenie człowieka w ciągu całego życia, jako elementy dziedziny poznania pedagogicznego, mogą być w pełni opisywane, wyjaśniane, rozumiane, interpretowane, weryfikowane i projektowane wówczas, gdy badane są nie tylko w wymiarze faktów, zjawisk i procesów mających miejsce tu i teraz. Szansa pełnego poznania rodzi się wówczas, gdy uwzględni się parametry życia człowieka, którymi są czas i przestrzeń, a zatem gdy uwzględni się kontekst historyczny i przestrzenny. Powinno to skłaniać do wiązania badań diagnostycznych, wyjaśniających, badań istotnościowych (hermeneutyczno-fenomenologicznych) z badaniami historycznymi i porównawczymi (Palka, 2006: 69).

Bazując na tej tezie oraz nawiązując do wcześniejszych uwag, można przyjąć, że układ glottodydaktyczny, wyrażający działalność i relacje nauczyciela języków obcych oraz jego uczniów, a także system glottodydaktyczny, 
w którym ów układ jest integralnie osadzony i pod którego wpływem niewątpliwie pozostaje, pod względem budowy i zasady funkcjonowania nie różnią się wielce od układów i systemów kształcenia innych przedmiotów. Stąd i w sposobie ich naukowego poznania oraz naukowej weń ingerencji można doszukiwać się analogii. Oczywiście, gwoli ścisłości, trzeba wskazać na pewną cechę różnicującą te układy/systemy. Choć nie godzi ona w logikę niniejszych rozważań, to jednak nie powinna pozostać przemilczana. Otóż wspomniana różnica przejawia się $w$ tym, że o ile w zwykłym układzie komunikacyjnym, właściwym systemom kształcenia innych niż język obcy przedmiotów, przedmiotem przekazu między nadawcą a odbiorcą są informacje semantyczne uogólniając: wiedza przedmiotowa - przekazywane za pomocą języka znanego zarówno nauczycielowi, jak i uczniom, to w układzie glottodydaktycznym przedmiotem przekazu jest - w ujęciu metaforycznym - język, który znany jest nauczycielowi, podczas gdy dla jego uczniów pozostaje obcym, nieznanym; zwłaszcza w pierwszej fazie nauki (por. Grucza, 1978: 39).

W tym miejscu warto nawiązać do rozbudowanego modelu glottodydaktyki, w którym wokół układu glottodydaktycznego, gdzie główne role odgrywają nauczyciel oraz uczeń, zlokalizowano oddziałujące nań, współzależne od siebie, różnorodne czynniki zewnętrzne, tworzące kontekst procesu glottodydaktycznego. Są to: cele polityki oświatowej i powiązane z nimi programy nauczania, warunki organizacyjne kształcenia językowego, społeczne zapotrzebowanie na znajomość danego języka obcego, kontekst społecznogrupowy, system kształcenia i doskonalenia glottodydaktycznego nauczycieli języków obcych, rodzinno-środowiskowe uwarunkowania i aspiracje, a także materialna obudowa procesu glottodydaktycznego, czyli wszelkiego rodzaju media i materiały glottodydaktyczne. System ten, nazwany systemem glottodydaktycznym, stanowi jednak zaledwie część całościowego modelu glottodydaktyki. Jest obszarem typowej praktyki dydaktycznej, a więc nauczania i uczenia się języków obcych w różnych formach i modelach kształcenia. Jednocześnie stanowi bazę empiryczną dla działalności naukowej. Na działalność tę składają się: 1) „glottodydaktyka czysta” - teoretyczny, stale rozbudowywany, fundamentalny zbiór wiedzy o całym układzie glottodydaktycznym, w tym właściwych dla niej twierdzeń, generalizacji, praw i ogólnych postulatów; 2) „glottodydaktyka stosowana" - pozwalająca metodami naukowymi badać i unowocześniać dotychczasowe oraz opracowywać zupełnie nowe metody nauczania i strategie uczenia się języków obcych; 3) „glottodydaktyka praktyczna" - której głównym zadaniem jest wdrażanie i weryfikacja w systemie glottodydaktycznym metod i strategii dostarczonych przez glottodydaktykę stosowaną (Woźniewicz, 1987: 88; por. Pfeiffer, 2001: 21). 
Temat niniejszych rozważań obliguje zaś do postawienia pytania o miejsce „refleksji” w tak złożonym, dynamicznym i w gruncie rzeczy w dalszym ciągu jeszcze otwartym układzie, gdzie wyraźnie rysują się granice czystej teorii, nauki stosowanej i dydaktyki praktycznej. Dynamikę tę należy z pewnością przypisać fluktuacji: nauczycieli, uczniów oraz innych uczestników układu i systemu glottodydaktycznego, a także kadry naukowej (na poziomie nauki formalnej, akademickiej). Implikuje ją przede wszystkim ich rozwój osobniczy, kompetencyjny, zawodowy, ale i proces naturalnej zastępowalności pokoleń. Nie mniej istotne dla glottodydaktyki ujmowanej całościowo, jak i dla jej poszczególnych subdziedzin, są: postęp cywilizacyjny, szeroko pojęte zmiany geopolityczne i społeczno-kulturowe, związana z tym rekonstrukcja systemów kształcenia obcojęzycznego, w końcu rozwój samej glottodydaktyki jako dyscypliny naukowej oraz ewolucja dyscyplin, z których dorobku jest ona zmuszona korzystać. To właśnie ta dynamika, te często głębokie, niekiedy wręcz rewolucyjne zmiany na każdym etapie, w każdym elemencie zarysowanej tu całości - glottodydaktyki - stanowią o jej niewyczerpalnym potencjale badawczym. To właśnie ta dynamika i rozwój nie tylko jakościowy, ilościowy czy rodzajowy, ale również rozwój czasoprzestrzenny, skłaniają bądź przynajmniej powinny skłaniać do refleksji - tak naukowej, jak i praktycznej, typowo użytkowej. $Z$ jednej strony refleksja powinna być zatem osadzona w rzeczywistości współczesnej, a więc koncentrować się na wydarzeniach, zjawiskach, procesach, przedmiotach, a w końcu podmiotach obecnych "tu” i „teraz”. Z drugiej strony nie może nie uwzględniać ona historycznego bagażu, jaki sobą reprezentuje glottodydaktyka jako całość.

Analizując wybrane studia empiryczne z zakresu glottodydaktyki, jak również podręczniki metodologii badań glottodydaktycznych, łatwo dostrzec, że metoda biograficzna nie cieszy się szczególnym zainteresowaniem, przynajmniej nie w pełnym jej wymiarze. Choć techniki introspekcji, retrospekcji czy choćby analiza dzienników i pamiętników, tak nauczycieli, jak i uczących się - jakże bliskie tej metodzie - są znane i powszechnie wykorzystywane przez badaczy glottodydaktyków, z pełną świadomością ich wad i zalet, to służą raczej wydobywaniu informacji, także refleksji, na temat niedalekiej przeszłości, dotyczących najczęściej konkretnego ćwiczenia, materiału nauczania, metody, strategii, sekwencji lekcji, rocznego, rzadziej kilkuletniego cyklu zajęć itp. Trudno tu zatem mówić o badaniach biograficznych, które pozwalałyby na pozyskanie kompleksowej refleksji o charakterze retrospektywnym, a więc takiej, która jest czyniona czy też budowana przez podmiot badania "tu” $\mathrm{i}$ „teraz" na podstawie wspomnień sięgających daleko w przeszłość. A to właśnie ta jej forma wydaje się najcenniejsza. Pozwala bowiem, przy właściwie zaprojektowanych badaniach, na zgromadzenie 
informacji dotyczących szeroko pojętych historycznych uwarunkowań kształcenia obcojęzycznego, w którym to procesie uczestniczył podmiot badania - na różnych etapach swojego życia, a zatem i rozwoju osobistego oraz kompetencyjnego, a przy tym często $w$ zmieniających się okolicznościach społeczno-kulturowych. Co więcej, pozwala także na pozyskanie refleksji o charakterze porównawczym, w pewien sposób wartościujących zjawiska, zdarzenia, procesy, metody, materiały itd., z jakimi podmiot ten spotkał się kiedyś i których kiedyś doświadczył, i z jakimi spotyka się dzisiaj. Dodać więc należy, wartościujących w dwójnasób: w odniesieniu do ówczesnych realiów, jak i do stanu obecnego, kiedy zasoby jego językowych, kulturowych czy po prostu społecznych doświadczeń oraz wiedzy są nieporównywalnie większe. Refleksje tego typu mogą okazać się wartością nieprzecenioną zwłaszcza dla młodych badaczy, ale i praktyków, którzy częstokroć zachłystują się nowymi technologiami, współczesną metodyką, zapominając o tym, że także w przeszłości ludzie uczyli się języków obcych i nierzadko efekty tej nauki, mimo że bez tak zaawansowanego wsparcia, były porównywalne, a być może i lepsze aniżeli dzisiaj.

Na pytania: Jak to było dokładnie? i Czemu dziś jest inaczej?, i zapewne na wiele innych pytań, odpowiedź mogą przynieść właśnie badania biograficzne. Również takie, które są skoncentrowane nie tyle na dotarciu do naocznych świadków bądź uczestników systemów glottodydaktycznych sprzed lat - tu przecież możliwości są ograniczone i kończą się na badaniach z udziałem najstarszych seniorów - co na analizie wszelkich informacji uwiecznionych na piśmie bądź w obrazie, a dotyczących badawczo wartościowych postaci, instytucji, systemów. Informacje te mogą występować pod postacią: opublikowanych materiałów dydaktycznych, wokabularzy, uczniowskich zeszytów, dzienników szkolnych, dzienników innych, pamiętników, listów, zdjęć, szkiców, ale także przedmiotowo ukierunkowanych sprawozdań statystycznych, raportów wynikowych, planów zajęć, konspektów lekcji, programów nauczania, strategii politycznych czy choćby rozpraw naukowych i/lub pseudonaukowych, w tym dzienników z obserwacji i badań, których co najmniej kilka weszło do obiegu naukowego, dając impuls do rozwoju myśli, która z biegiem lat, przy udziale niezliczonej rzeszy osób, przerodziła się $w$ dyscyplinę naukową. Jeśli wybiec myślą w przyszłość, do katalogu tego można by dopisać wszelkiego typu materiały digitalizowane, jak: nagrania audio/wideo z lekcji pokazowych, wideorejestracje z badań, foniczne zapisy wszelkiego typu wywiadów, elektroniczne dzienniki szkolne, programy studiów, e-podręczniki, blogi internetowe itd. One także, w przyszłości, zostaną zaliczone do materiałów historycznych. O ile będzie można skoncentrować je wokół wybranej, poznawczo interesującej 
i badawczo wartościowej postaci lub instytucji, ich badanie na podstawie metody biograficznej będzie z pewnością zasadne.

Odrębnej uwagi wymaga literatura przedmiotu, której twórcami byli i są przedstawiciele świata nauki. Dziś są to glottodydatycy. Wcześniej byli to lingwiści. Jeszcze wcześniej myśliciele, pasjonaci, nauczyciele praktycy - dla rozwoju myśli glottodydaktycznej nie mniej ważni. Ich twórczość, niewątpliwie naznaczona refleksją, często poprzedzoną wnikliwymi studiami, wyróżnia się wielce spośród innych biograficznych materiałów. Także przez to, że w wielu przypadkach, współcześnie najczęściej, ma charakter naukowy. Trzeba przyznać, że wielokrotnie staje się ona przedmiotem kolejnych rozpraw, gdzie naturalną rzeczą - wedle zasad naukowego stylu pisarskiego - jest przeprowadzenie analizy dotychczasowego stanu badań nad jakimś zagadnieniem. Warunkiem koniecznym jest więc dla badacza odwołanie się do badań poprzedników, ustosunkowanie się do stawianych przez nich tez i sądów, a w konsekwencji na ich podstawie i w konfrontacji z wynikami innych badań, w szczególności własnych, zbudowanie osobistej refleksji na interesujący temat. Nie można jednak nazwać takiej działalności badaniami biograficznymi. Inaczej rzecz się ma, gdy badacz postawi sobie za cel kompleksową analizę dorobku danego autora - również badacza. Ma on wówczas możliwość prześledzenia ewolucji jego myśli naukowej, zapoznania się z jego refleksjami poddawanymi rekonstrukcji w kolejnych dziełach, pod warunkiem, że te podejmują ten sam problem. W takim przypadku z dużą dozą śmiałości można takim studiom przypisać status badań biograficznych. Co więcej, zapoznając się z dorobkiem niektórych myślicieli, zwykle pionierów w swojej dziedzinie, można doszukać się w ich pracach właściwości autobiograficznych. Mają oni bowiem w zwyczaju powoływać się na własne, wcześniejsze badania i budowane na ich podstawie tezy czy całe koncepcje teoretyczne, nierzadko odnosząc się do nich krytycznie. W świetle zaprezentowanych rozważań, należy to uznać za przejaw refleksji szczególnej, gdyż naukowo udokumentowanej i umotywowanej, co nie zdarza się np. w przypadku biograficznej autoanalizy czynionej przez seniorów uczących się języków obcych. Tu jednak należy wyraźnie podkreślić, że każdy przejaw refleksji na temat uczenia się i nauczania języków obcych, wydobytej dzięki metodzie biograficznej, ma wartość niebagatelną dla rozwoju dyscypliny naukowej, jaką jest dziś glottodydaktyka. A choć powyższe przypadki są skrajne i z przyczyn oczywistych nieporównywalne, to w pewnym przynajmniej zakresie, ukazują istotę problemu. Multiplikacja perspektyw badawczych, tak podmiotowa, jak i w wymiarze czasoprzestrzennym, nie powinna być wobec powyższego negowana, lecz raczej dobitnie postulowana - przy założeniu, że dopełnione zostaną zasady naukowej rzetelności i obiektywizmu, co akurat w badaniach biograficznych może stanowić poważne wyzwanie. 


\section{Zakończenie}

Rozważania niniejsze należy traktować jako zaproszenie do dyskusji na temat możliwości wykorzystania badań biograficznych w procesie budowania i jednocześnie weryfikacji dorobku glottodydaktyki, tak na etapie teoriotwórczym i badań empirycznych, jak również w praktyce dydaktycznej. Konferencja naukowa poświęcona zagadnieniu "refleksji” w uczeniu się i nauczaniu języków obcych (Wrocław 2013), gdzie zostały przedstawione, wydawała się dobrą ku temu okazją.

W ubiegłym roku, na innej konferencji, zorganizowanej pod patronatem Komisji Europejskiej i Fundacji Rozwoju Systemu Edukacji, zwracając się do ekspertów edukacji językowej, nauczycieli, studentów, doktorantów, pracowników akademickich, władz oświatowych odpowiedzialnych za kształtowanie polityki językowej oraz partnerów społecznych aktywnie działających w dziedzinie nauki języków obcych, jedna z czołowych przedstawicielek polskiej glottodydaktyki postulowała $\mathrm{w}$ retrospektywnym wywodzie, aby nie przekreślać „tradycyjnych" metod nauczania, bo podobnie jak te, które dziś wydają się „ultranowoczesne", i te zakorzenione w dalekiej przeszłości mają swoje zasługi w nauce języków obcych, na co dowodem są biografie wielu postaci, w różny sposób i w różnym czasie wsławionych na kartach historii Polski i Europy (por. Komorowska, 2012). Podążając za tą radą i wcielając się w rolę początkującego badacza, dopiero od niedawna zainteresowanego tym zakresem problemowym, pisząca te słowa stawia zatem pytania o istotę badań biograficznych, ich sens, dotychczasową historię oraz wyniki w dziedzinie obcojęzycznego kształcenia? Jednocześnie prosi o wszelkie sugestie - wypadałoby rzec: refleksje które wskażą trop do dalszych poszukiwań w tej materii.

\section{BIBLIOGRAFIA}

Chudy, W. 2006. „Refleksja” (w:) Encyklopedia Pedagogiczna XXI wieku. Tom V RSt. Pilch, T. (red.). 2006. Warszawa: Wydawnictwo Akademickie Żak: 68-72.

Dakowska, M. 2008. „Determinanty przedmiotu badań glottodydaktycznych” (w:) Kultury $i$ języki: poznawać - uczyć się - nauczać. Księga jubileuszowa dla Pani Profesor Elżbiety Zawadzkiej-Bartnik z okazji 65. urodzin. Jaroszewska, A., Torenc, M. (red.). 2008. Warszawa: Instytut Germanistyki Uniwersytetu Warszawskiego: 39-50.

Doroszewski, W. (red.). 1963. Słownik języka polskiego. Tom VII Pri-R. Warszawa: Państwowe Wydawnictwo Naukowe.

Grucza, F. 1978. „Glottodydaktyka, jej zakres i problemy” (w:) Przeglad Glottodydaktyczny, 1: 29-44. 
Kic-Drgas, J. 2010. „Rola refleksji w nauczaniu języków obcych” (w:) Lingwistyka Stosowana. Przeglad, 2: 113-120.

Komorowska, H. 2012. Jak wczoraj i dziś kształcenia językowego wpłynq na edukacyjne jutro? Wystąpienie plenarne wygłoszone w dniu 24 września 2012 r. w Bibliotece Uniwersyteckiej w Warszawie podczas konferencji „Nowe Technologie i Media Społecznościowe w Edukacji Językowej".

Łobocki, M. 2006. Metody i techniki badań pedagogicznych. Kraków: Oficyna Wydawnicza „Impuls”.

Milerski, B., Śliwerski, B. (red.). 2000. Leksykon PWN: Pedagogika. Warszawa: Wydawnictwo Naukowe PWN.

Palka, S. 2006. Metodologia - Badania - Praktyka pedagogiczna. Gdańsk: Gdańskie Wydawnictwo Psychologiczne.

Pfeiffer, W. 2001. Nauka języków obcych. Od praktyki do praktyki. Poznań: Wydawnictwo WAGROS.

Rzepa, T., Leoński, J. (red.). 1993. O biografii i metodzie biograficznej. Poznań: Wydawnictwo "Nakom".

Sipińska, D. 2004. „Metoda biograficzna” (w:) Encyklopedia Pedagogiczna XXI wieku. Tom III M-O. Pilch, T. (red.). 2004. Warszawa: Wydawnictwo Akademickie Żak: $156-167$.

Sobol, E. (red.). 2002. Nowy słownik języka polskiego. Warszawa: Wydawnictwo Naukowe PWN.

Wilczyńska, W. 2010. „Obszary badawcze glottodydaktyki” (w:) Neofilolog, 34: 21-35.

Wilczyńska, W., Michońska-Stadnik, A. 2010. Metodologia badań w glottodydaktyce. Wprowadzenie. Kraków: Wydawnictwo Avalon.

Woźniewicz, W. 1987. Kierowanie procesem glottodydaktycznym. Warszawa: Państwowe Wydawnictwo Naukowe. 